\title{
The Effects of Good Corporate Governance and Company Status on The Company Financial Performance
}

(Case Study on Corporate Governance Perception Index Participants for the 2015-2019 Period)

\section{Rahmadoni}

Master of Management Study Program, Bakrie University, Jakarta, Indonesia

\begin{abstract}
Article Info

Volume 8, Issue 4

Page Number : 348-359

\section{Publication Issue}

July-August-2021

\section{Article History}

Accepted : 15 July 2021

Published : 24 July 2021

This study aims to examine the effect of Good Corporate Governance (GCG) and company status on the company's financial performance in companies participating in the 2015-2019 CGPI rating program organized by IICG and SWA Magazine. The sampling method of this research is purposive sampling method and follows certain criteria resulting in 13 sample companies. The analytical method of this research is multiple linear regression analysis with SPSS (Statistical Product and Service Solution) application tools. The results of the study indicate that Good Corporate Governance and company status have a significant influence on the company's financial performance and company status also has a significant influence on Good Corporate Governance.
\end{abstract}

Keywords : Good Corporate Governance, Company Status, Company Financial Performance

\section{INTRODUCTION}

Good Corporate Governance (GCG) is a basic principle in a good corporate management process based on laws and regulations and business ethics. With the implementation of good and correct governance principles in the company, it will encourage an increase in company performance and long-term economic value for investors and stakeholders.

The Indonesian Institute for Corporate Governance (IICG) explains that the concept of Corporate
Governance (CG) is a collection of procedures for leading and controlling company operations in accordance with stakeholder expectations. CG is a structure, system and process carried out by all elements in the company to add long-term and sustainable value. CG can also create a conducive environment to support efficient growth.

The Government of Indonesia through the Coordinating Minister for Economy, Finance and Industry in 1999 formed the National Committee on Governance Policy (Komite Nasional Kebijakan Governance-KNKG) whose role is to make the code 
or rules for GCG. This committee is tasked with codifying the principles of corporate governance and developing the institutional framework for implementing the Decree of the Coordinating Minister for Economy, Finance and Industry No. 1/M.EKUIN/08/1999. Subsequently, in March 2000, KNKG succeeded in compiling rules for GCG (Daniel, 2003) which were then applied to all state-owned companies and private companies listed on the Jakarta Stock Exchange; now the Indonesia Stock Exchange (IDX) (Lukviarman, 2004).

Theoretically, GCG practices can encourage increased company performance because they are able to reduce risks that may have been made by directors through decisions that are personally beneficial. This can increase the confidence of investors which makes them more interested in investing or adding their capital. According to the calculations of the World Bank (Djalil, 2000), weak implementation of CG is one of the factors causing the severity of the crisis in Asia due to limited information on financial performance and company liabilities, lack of supervision by the commissioners of management, and lack of encouragement in the form of fair competition for create efficiency in the company.

The company's commitment to implementing GCG can determine the company's performance. Companies that participate in the CG rating organized by IICG are expected to be able to implement good CG so that they are able to encourage increased corporate value. The better the implementation of CG, based on the results of the assessment of the Corporate Governance Perception Index (CGPI), the higher the level of company compliance with corporate governance will also be. This can make the company's performance better.

The results of research by Darwis (2009) regarding companies listed on the IDX and following a survey conducted by IICG for the period 2006-2008 show that the implementation of GCG is able to affect the company's performance. This means that the company's performance will increase if it implements CG properly. Theoretically, GCG practice is able to encourage an increase in company value and financial performance, reduce the risk of making personally profitable decisions by the Board of Directors, and in general with the implementation of GCG, investors' confidence will increase to invest their capital which will accelerate the improvement of company performance.

On the other hand, bad CG practices will lead to reduced investor confidence. This is supported by the results of a survey by McKinsey \& Company (2000) which states that investors pay equal attention to CG, financial performance, and growth potential, especially in emerging markets. Investors have a tendency to avoid companies that do not implement CG well because they believe CG is a determining qualitative criterion. In this case, Indonesia is one of the countries with the worst quality of CG implementation in Asia in the view of investors.

The issue of GCG in Indonesia has only started to become a concern since the time of the Indonesian crisis in 1998. Research conducted using a sample of companies in Asia, ie, in Indonesia, Korea, Malaysia, the Philippines, and Thailand, shows that the variables related to GCG have an impact strong impact on company performance during the 19971998 East Asian crisis (Mitton, 2000).

A study by the Asian Development Bank (ADB) found that weak governance structures, poor investment, and risky financing practices contributed to the sharp economic recession in 1997-1998 (Zhuang, Edwards, Webb, \& Capulong, 2000). This became a trigger for corporate governance reform in Asia, including in Indonesia, which was driven by the crisis conditions that occurred at that time. 
An overview of the condition of GCG implementation in Indonesia can be found in the GCG implementation survey by the IIGC in collaboration with SWA Magazine on public companies in Indonesia with a response rate of less than $10 \%$ of the total 332 respondents. Meanwhile, similar surveys conducted by developed countries were followed by more than $70 \%$ of respondents.

Indonesia's weak economy is the result of inefficient management of the economy and the business sector coupled with a fragile banking system, especially at the micro level. Although BAPEPAM has issued several regulations aimed at increasing transparency and consistency in the implementation of its economic policies, the implementation of GCG is still not running optimally.

For example, research conducted by Widodo (2012) on 115 companies that participated in the CGPI survey in 2010-2012 with a sample of 73 companies, concluded that companies will have more efficient financial performance if they implement GCG. This will also yield greater profits. Management that works effectively and efficiently will be able to reduce agency costs and to minimize the risk.

The implementation of GCG in company activities can be an important point for companies to gain longterm profits and be able to compete in global business. Investors pay equal attention to GCG and the company's financial performance because they believe that companies that have implemented GCG practices mean that they have tried to minimize the risk of decisions that will provide individual benefits. This will also improve the company's performance and can maximize the value of the company. The purpose of implementing CG is not only for the implementation of GCG principles but for a larger purpose, namely to increase the value of the company. Therefore, this study focuses on companies that participate in the 2015-2019 CGPI rating program organized by IICG and SWA Magazine.

\section{RESEARCH METHODS}

The population of this study was companies that participated in the CGPI survey conducted by IICG in collaboration with SWA Magazine in 2015 - 2019, which were 58 companies. The sample of this research was obtained by using purposive sampling method with the sampling technique following certain criteria. This study followed the following criteria in selecting the research sample:

Table 1 Sample Selection Criteria

\begin{tabular}{|l|c|}
\hline Population & Total \\
\hline $\begin{array}{l}\text { Companies that participated in the } \\
\text { assessment of the Corporate }\end{array}$ & 58 \\
Governance Perception Index during & \\
the 2015-2019 period & \\
\hline Criteria & \\
\hline $\begin{array}{l}\text { consistently participate in the } \\
\text { Corporate Governance Perception }\end{array}$ & \\
Index rating program during the 2015- & \\
2019 period Companies that did not & $(43)$ \\
\hline $\begin{array}{l}\text { 2. Companies that did not provide } \\
\text { 2015-2019 ROE data in the 2019 annual }\end{array}$ & $(2)$ \\
report on the companies' official & \\
website & \\
\hline Total samples that meet the criteria & 13 \\
\hline
\end{tabular}

Source: IICG which has been processed

The data source is secondary data. The secondary data used are CGPI research program reports and ratings for the 2015-2019 period obtained from IICG and the company's annual report for the 2019 period obtained from the official website of each company.

The data collection technique of this study is archival research where the data obtained comes from 
historical data that has existed previously, then processed, stored, and presented in a certain format and by certain parties for certain interests and has an objective nature.

This study uses a data processing tool in the form of statistical software SPSS. The analysis technique in answering research problems uses regression between the dependent variable and the independent variable through multiple linear regression analysis which will show the influence between the dependent variable and the independent variable. This study tested the regression equation model as follows:

Regression Model I

$$
Y=\alpha+\beta_{1} X_{1}+\beta_{1} X_{2}+€
$$

Indexes:

$\mathrm{Y} \quad$ : Company Financial Performance

$\alpha \quad:$ Constant

$\beta_{1} \& \beta_{2} \quad$ : Regression Coefficient
$\mathrm{X}_{1}$
: GCG
$\mathrm{X}_{2}$
: Company Status
$€$
: Error

Regression Model II

$$
Y=\alpha+\beta_{1} X_{1}+€
$$

Indexes:

$$
\begin{array}{ll}
Y & : \text { GCG } \\
\alpha & : \text { Constant } \\
\beta_{1} & : \text { Regression Coefficient } \\
X_{1} & : \text { Company Status } \\
€ & : \text { Error }
\end{array}
$$

\section{RESULTS AND DISCUSSION}

The results of descriptive statistical testing of the GCG variable on Company Status and Company Financial Performance from 2015-2019 are presented in the table below:

Table 2 Descriptive Statistics Test Results

\begin{tabular}{|lr|r|r|r|r|}
\hline & \multicolumn{7}{c|}{ Descriptive Statistics } \\
& N & \multicolumn{1}{c|}{ Minimum } & \multicolumn{1}{c|}{ Maximum } & \multicolumn{1}{c|}{ Mean } & \multicolumn{1}{c|}{ Std. Deviation } \\
\hline Status X2 & 65 & 1 & 2 & 1.54 & .502 \\
\hline Governance X1 & 65 & 71.98 & 94.94 & 84.9472 & 5.59401 \\
\hline Performance Y & 65 & -46.67 & 67.57 & 15.8508 & 12.88072 \\
\hline Valid N (listwise) & 65 & & & & \\
\hline
\end{tabular}

The results of descriptive statistical testing of the GCG variable on Company Status and Company Financial Performance from 2015-2019 are presented in the table below:

\begin{tabular}{|lr|r|r|r|r|}
\hline & \multicolumn{7}{c|}{ Descriptive Statistics } \\
& N & \multicolumn{1}{c|}{ Minimum } & \multicolumn{1}{c|}{ Maximum } & \multicolumn{1}{c|}{ Mean } & \multicolumn{1}{c|}{ Std. Deviation } \\
\hline Status X2 & 65 & 1 & 2 & 1.54 & .502 \\
\hline Governance X1 & 65 & 71.98 & 94.94 & 84.9472 & 5.59401 \\
\hline Performance Y & 65 & -46.67 & 67.57 & 15.8508 & 12.88072 \\
\hline Valid N (listwise) & 65 & & & & \\
\hline
\end{tabular}

Table 2. Descriptive Statistics Test Results

The Company Status variable which is dummy data has a value range of 1 or 2. For private or non-tbk companies it is given a value of 1 , and for public companies or tbk it is given a value of 2 . The average value of the Company Satus variable is 1.54 with a standard deviation of 0.502 . 
The GCG variable proxied by the CGPI score has a range of values from 71.98 to 94.94 . The lowest score was obtained by PT Asuransi Jiwa Inheath Indonesia in 2015 and the highest score was obtained by PT Bank Mandiri (Persero) Tbk in 2019. The average CGPI score shows the number 84.9472 and the standard deviation is 5.59401 .

The ROE percentage variable which is the Company's Financial Performance has a value range from -46.67 to 67.57. The lowest percentage was obtained by PT Bakrie \& Brothers Tbk in 2018, and the highest percentage was also obtained by PT Bakrie \& Brothers Tbk in 2016. The average ROE percentage showed a value of 15.8508 , while the standard deviation showed a value of 12.88072 .

\section{A. Normality Test}

Based on the results of the analysis for the Normality Test in Table 3, it is known that the significance value of each variable is greater than 0.05 , namely 0.076 for the $\mathrm{Y}$ variable, 0.165 for the $\mathrm{X} 1$ variable and 0.080 for the $\mathrm{X} 2$ variable. Thus it can be said that all variables are normally distributed, and the Normality Test has been fulfilled and the data obtained can be analyzed.

One-Sample Kolmogorov-Smirnov Test

\begin{tabular}{|ll|r|r|r|}
\hline & & Kinerja Y & Status X2 & Tata Kelola X1 \\
\hline N & & 65 & 65 & 65 \\
Normal Parameters & & 15.40 & 1.5385 & 84.35 \\
& Mean & 12.801 & 0.50240 & 5.605 \\
Most Extreme Differences & Std. Deviation & 0.159 & 0.359 & 0.139 \\
& Absolute & 0.153 & 0.320 & 0.065 \\
& Positive & -0.159 & -0.359 & -0.139 \\
Kolmogorov-Smirnov Z & Negative & 1.278 & 2.897 & 1.117 \\
Asymp. Sig. (2-tailed) & & 0.076 & 0.080 & 0.165 \\
\hline
\end{tabular}

a. Test distribution is Normal.

Table 3. Hasil Uji Normalitas

\section{B. Multicollinearity Test}

Table 4 shows that the tolerance value for the $\mathrm{X} 1$ variable is 0.805 which is greater than 0.10 with a VIF value of 1.242 which is smaller than 10 , and for the $\mathrm{X} 2$ variable the tolerance value is 0.805 which is greater than 0.10 with a VIF value of 1.242 less than 10 . Thus, it can be said that there is no multicollinearity in the regression model.

\section{Coefficients $^{\mathrm{a}}$}

\begin{tabular}{|ll|r|c|}
\hline \multirow{2}{*}{ Model } & \multicolumn{2}{|c|}{ Collinearity Statistics } \\
\cline { 3 - 4 } & & Tolerance & \multicolumn{1}{c|}{ VIF } \\
\hline 1 & (Constant) & & \\
& Status X2 & 0.805 & 1.242 \\
& Governance X1 & 0.805 & 1.242 \\
\hline
\end{tabular}




\begin{tabular}{|c|c|c|c|}
\hline \multicolumn{4}{|c|}{ Coefficients $^{a}$} \\
\hline \multirow{2}{*}{\multicolumn{2}{|c|}{ Model }} & \multicolumn{2}{|c|}{ Collinearity Statistics } \\
\hline & & Tolerance & VIF \\
\hline \multirow[t]{3}{*}{1} & (Constant) & & \\
\hline & Status X2 & 0.805 & 1.242 \\
\hline & Governance X1 & 0.805 & 1.242 \\
\hline
\end{tabular}

a. Dependent Variable: Performance Y

Table 4 Multicollinearity Test Results

\section{Heteroscedasticity Test}

Table 5 shows that the sig value of each variable is greater than 0.05 , where for $\mathrm{X} 1$ the sig value is 0.089 which is greater than 0.05 , and 0.101 for $\mathrm{X} 2$ is greater than 0.05 . So it can be concluded that there is no heteroscedasticity in this study.

\section{Coefficients $^{\mathrm{a}}$}

\begin{tabular}{|c|c|c|c|c|c|c|}
\hline \multirow{2}{*}{\multicolumn{2}{|c|}{ Model }} & \multicolumn{2}{|c|}{ Unstandardized Coefficients } & \multirow{2}{*}{$\begin{array}{c}\begin{array}{c}\text { Standardized } \\
\text { Coefficients }\end{array} \\
\text { Beta }\end{array}$} & \multirow[b]{2}{*}{$\mathrm{t}$} & \multirow[b]{2}{*}{ Sig. } \\
\hline & & B & Std. Error & & & \\
\hline \multirow[t]{3}{*}{1} & (Constant) & 81.032 & 16.974 & & 4.774 & 0.000 \\
\hline & Governance X1 & 1.033 & 0.216 & 0.570 & 4.773 & 0.089 \\
\hline & Status X2 & 8.322 & 2.414 & .412 & 3.448 & 0.101 \\
\hline
\end{tabular}

a. Dependent Variable: Abs_Res

Table 5 Heteroscedasticity Test Results

\section{Uji Autokorelasi}

Hasil Uji Durbin-Watson yang digunakan dalam pengujian Model Regresi I sama dengan 1,202, maka kesimpulannya tidak terjadi autokorelasi karena nilai dw terletak antara du dan 4-du.

Model Summary ${ }^{\mathrm{b}}$

\begin{tabular}{|l|r|r|r|r|r|}
\hline \multirow{2}{*}{ Model } & R & R Square & Adjusted R Square & \multicolumn{2}{|c|}{$\begin{array}{c}\text { Std. Error of the } \\
\text { Estimate }\end{array}$} \\
\hline 1 & $0.750^{\mathrm{a}}$ & 0.690 & 0.619 & 1.407 & Durbin-Watson \\
\hline
\end{tabular}

Table 6. Autocorrelation Test Results (Model I)

a. Predictors: (Constant), Governance X1, Status X2

b. Dependent Variable: Performance Y

The Durbin-Watson test results in the Regression Model II test are equal to 1.142, so the conclusion is that there is no autocorrelation because the value of $d w$ lies between du and 4-du. 
Model Summary ${ }^{\mathrm{b}}$

\begin{tabular}{|c|c|c|c|c|c|}
\hline Model & $\mathrm{R}$ & R Square & Adjusted R Square & $\begin{array}{l}\text { Std. Error of the } \\
\text { Estimate }\end{array}$ & Durbin-Watson \\
\hline 1 & $0.442^{\mathrm{a}}$ & 0.195 & 0.182 & 5.069 & 1.142 \\
\hline
\end{tabular}

a. Predictors: (Constant), Status X2

b. Dependent Variable: Governance X1

\section{E. Coefficient of Determination Test $\left(R^{2}\right.$ Test $)$}

In the SPSS calculation results for Regression Model I in Table 8, it can be seen that the coefficient of determination or R square is 0.690 or equal to $69 \%$. This indicates that the GCG variable (X1) and the Company Status variable (X2) simultaneously affect the Company's Financial Performance variable (Y) by $69 \%$ while the remaining $31 \%$ is influenced by other variables outside this regression equation or variables that are not examined.

\begin{tabular}{|l|r|r|r|r|r|}
\hline \multicolumn{1}{|c|}{ Model Summary $^{\mathrm{b}}$} \\
\hline 1 & $\mathrm{R}$ & R Square & Adjusted R Square & $\begin{array}{c}\text { Std. Error of the } \\
\text { Estimate }\end{array}$ & Durbin-Watson \\
\hline & $0.750^{\mathrm{a}}$ & 0.690 & 0.619 & 1.407 & 1.202 \\
\hline
\end{tabular}

Table 8 Results of the Coefficient of Determination (Model I)

a. Predictors: (Constant), Governance X1, Status X2

b. Dependent Variable: Performance Y

From the calculation results of SPSS for Regression Model II in Table 9, it can be seen that the value of the coefficient of determination or R square is 0.195 or equal to $19.5 \%$. This indicates that the Company Status variable (X2) has an effect on the GCG variable (X1) by $19.5 \%$ while the remaining $80.5 \%$ is influenced by other variables outside this regression equation or variables that are not examined.

Model Summary

\begin{tabular}{|c|c|c|c|c|c|}
\hline Model & $\mathrm{R}$ & R Square & Adjusted R Square & $\begin{array}{l}\text { Std. Error of the } \\
\text { Estimate }\end{array}$ & Durbin-Watson \\
\hline 1 & $0.442^{\mathrm{a}}$ & 0.195 & 0.182 & 5.069 & 1.142 \\
\hline
\end{tabular}

Table 9 Coefficient of Determination Test Results (Model II)

a. Predictors: (Constant), Status X2

b. Dependent Variable:Governance X1 


\section{F. Simultaneous Significance/Effect Test (Statistical Test F)}

Table 10 shows the significance value (Sig) in the F Test is 0.014 for Regression Model I. Because Sig 0.014 is smaller than 0.05 , as the basis for decision making in the F Test can be concluded that GCG (X1) and Company Status (X2) simultaneously have a significant effect on the company's financial performance (Y).

ANOVA $^{b}$

\begin{tabular}{|ll|r|r|r|r|r|}
\hline Model & & Sum of Squares & df & Mean Square & F & \multicolumn{1}{c|}{ Sig. } \\
\hline 1 & Regression & 944.148 & 2 & 472.074 & 3.067 & 0.014 \\
& Residual & 9543.452 & 62 & 153.927 & & \\
& Total & 10487.600 & 64 & & & \\
\hline
\end{tabular}

Table 10 F Statistical Test Results (Model I)

a. Predictors: (Constant), Governance X1, Status X2

b. Dependent Variable: Performance Y

In table 11 it is known that the significance value (Sig) in the F test is 0.000 in the Regression Model II. Because Sig 0.000 is smaller than 0.05 , as the basis for decision making in the F Test, it can be concluded that Company Status (X2) has a significant effect on GCG (X1).

ANOVA $^{\mathrm{b}}$

\begin{tabular}{|ll|r|r|r|r|r|}
\hline Model & & Sum of Squares & df & Mean Square & F & Sig. \\
\hline 1 & Regression & 392.390 & 1 & 392.390 & 15.274 & 0.000 a \\
& Residual & 1618.471 & 63 & 25.690 & & \\
& Total & 2010.862 & 64 & & & \\
\hline
\end{tabular}

Table 11 Results of F Statistical Test (Model II)
a. Predictors: (Constant), Status X2
b. Dependent Variable:Governance X1

\section{G. Individual Parameter Significance Test (Test Statistical t $)$}

Table 12 shows that the significance value (Sig) of the GCG variable (X1) Regression Model I is 0.019, which is smaller than 0.05 , so it can be concluded that hypothesis 2, namely the influence of GCG (X1) on the Company's Financial Performance ( $\mathrm{Y}$ ) is accepted.

Furthermore, for the variable Company Status (X2) in Regression Model I the value of sig 0.021 is smaller than 0.05 so it can be concluded that hypothesis 3: the effect of Company Status (X2) on the Company's Financial Performance $(\mathrm{Y})$ is accepted.

\section{Coefficients $^{\mathrm{a}}$}

\begin{tabular}{|l|c|c|c|c|c|}
\hline \multirow{2}{*}{ Model } & \multicolumn{2}{|c|}{$\begin{array}{c}\text { Standardized } \\
\text { Coefficients }\end{array}$} & & \\
\cline { 2 - 4 } & Unstandardized Coefficients & B & Std. Error & Beta & Sig. \\
\hline
\end{tabular}




\begin{tabular}{|c|c|c|c|c|c|c|}
\hline \multirow[t]{3}{*}{1} & (Constant) & 46.374 & 24.196 & & 1.917 & 0.040 \\
\hline & Status X2 & 8.178 & 3.441 & 0.321 & 2.377 & 0.021 \\
\hline & Governance X1 & 0.516 & 3.308 & 0.226 & 3.674 & 0.019 \\
\hline
\end{tabular}

Table 12 Results of the t-Statistical Test

(Model I)

a. Dependent Variable: Kinerja Y

In table 13, the variable Company Status (X2) in Regression Model II the value of Sig 0.000 is smaller than 0.05 so it can be concluded that hypothesis 1, namely the influence of Company Status (X2) on GCG (X1) is accepted.

\section{Coefficients ${ }^{\mathrm{a}}$}

\begin{tabular}{|c|c|c|c|c|c|c|}
\hline \multirow{2}{*}{\multicolumn{2}{|c|}{ Model }} & \multicolumn{2}{|c|}{ Unstandardized Coefficients } & \multirow{2}{*}{$\begin{array}{c}\text { Standardized } \\
\text { Coefficients }\end{array}$} & \multirow[b]{2}{*}{$\mathrm{t}$} & \multirow[b]{2}{*}{ Sig. } \\
\hline & & B & Std. Error & & & \\
\hline \multirow[t]{2}{*}{1} & (Constant) & 76.771 & 2.039 & & 37.643 & 0.000 \\
\hline & Status X2 & 4.929 & 1.261 & 0.442 & 3.908 & 0.000 \\
\hline
\end{tabular}

Table 13 Results of the t-Statistical

Test (Model II)

a. Dependent Variable: Governance X1

\section{H. Regression Analysis}

Multiple regression analysis was performed by comparing $t$ count with $t$ table and sig value with $\sigma 0.05$. In detail the results of multiple regression testing can be seen in Table 14 below:

\section{Coefficients $^{\mathrm{a}}$}

\begin{tabular}{|c|c|c|c|c|c|c|}
\hline \multirow{2}{*}{\multicolumn{2}{|c|}{ Model }} & \multicolumn{2}{|c|}{ Unstandardized Coefficients } & \multirow{2}{*}{$\begin{array}{c}\text { Standardized } \\
\text { Coefficients } \\
\text { Beta }\end{array}$} & \multirow[b]{2}{*}{$\mathrm{t}$} & \multirow[b]{2}{*}{ Sig. } \\
\hline & & B & Std. Error & & & \\
\hline \multirow[t]{3}{*}{1} & (Constant) & 46.374 & 24.196 & & 1.917 & 0.040 \\
\hline & Status X2 & 8.178 & 3.441 & 0.321 & 2.377 & 0.021 \\
\hline & Gonvernance X1 & 0.516 & 3.308 & 0.226 & 3.674 & 0.019 \\
\hline
\end{tabular}

Table 14 Hypothesis Testing Results (Model I)

a. Dependent Variable: Performance Y

Based on the table above, the estimation model can be analyzed as follows:

$$
Y=46,374+0,516(\mathrm{X} 1)+8,178(\mathrm{X} 2)
$$

Indexes:

Y : Company Financial Performance

X1 : GCG

X2 : Company Status

From the above equation it can be explained that: 
1. The constant value of 46.374 indicates that if the GCG and Company Status variables are zero, then the value of the Company's Financial Performance is 46.374 .

2. The GCG coefficient of 0.516 indicates that every one unit increase in GCG will result in an increase in the Company's Financial Performance of 0.516 units.

3. The Company Status coefficient of 8.178 indicates that each increase in Company Status by one unit will result in an increase in the Company's Financial Performance of 8.178 units.

Sementara untuk melihat pengaruh Status Perusahaan (X2) terhadap GCG (X1) dapat kita lihat dari Tabel 15 berikut:

\section{Coefficients $^{\mathrm{a}}$}

\begin{tabular}{|c|c|c|c|c|c|c|}
\hline \multirow{2}{*}{\multicolumn{2}{|c|}{ Model }} & \multicolumn{2}{|c|}{ Unstandardized Coefficients } & \multirow{2}{*}{$\begin{array}{c}\text { Standardized } \\
\text { Coefficients }\end{array}$} & \multirow[b]{2}{*}{$\mathrm{t}$} & \multirow[b]{2}{*}{ Sig. } \\
\hline & & B & Std. Error & & & \\
\hline \multirow[t]{2}{*}{1} & (Constant) & 76.771 & 2.039 & & 37.643 & 0.000 \\
\hline & Status X2 & 4.929 & 1.261 & 0.442 & 3.908 & 0.000 \\
\hline
\end{tabular}

a. Dependent Variable: Governance X1

Table 15. Results of Hypothesis Testing (Model II)

Based on the table above, the estimation model can be analyzed as follows:

$\mathrm{Y}=76,771+4,929(\mathrm{X} 2)$

Indexes:

$$
\begin{array}{ll}
\mathrm{Y} & : \mathrm{GCG} \\
\mathrm{X} 2 & : \text { Company Status }
\end{array}
$$

This equation explains that the coefficient value of Company Status is 4.929 which indicate that every one unit increase in Company Status will result in an increase in GCG of 4.929 units.

\section{IV.DISCUSSION}

\section{H1: Influence of Company Status on GCG}

These results indicate that Company Status has an effect on GCG because the significance value is 0.000 . Companies with a high level of regulation tend to apply the principles better in order to comply with applicable regulations (Iba \& Bariah, 2013). Especially for public companies, apart from the government, as well as regulations in the capital market and the OJK which seeks to encourage the implementation of GCG principles.

In addition, with the provision of information by companies that are easily accessible to the public, the company is considered to have implemented the principles of transparency and responsibility regarding the company's responsibility as part of the community to stakeholders and the environment in which the company is located, as well as its reputation is getting better

H2: The Effect of GCG on the Company's Financial

\section{Performance}

These results indicate that GCG has an effect on the Company's Financial Performance because the significance value is 0.019 . The results of this study are in accordance with the results of research 
conducted by Darwis (2009) which shows the implementation of GCG has a positive effect on company performance in companies listed on the IDX for the period 2006-2008. Theoretically, GCG practices can increase the value of the company, improve financial performance, reduce the risks that may be carried out by directors with decisions that benefit themselves, and in general increase investor confidence to invest their capital which has an impact on their performance.

On the other hand, bad CG practices can reduce investors' confidence. This is in line with the results of a survey conducted by McKinsey \& Company (2002) which shows that CG is the main concern of investors as well as financial performance and growth potential, especially for emerging markets. In this case they tend to avoid companies that are bad in implementing CG because it is seen as a determining qualitative criterion. And in the eyes of investors, Indonesia is one of the worst countries in Asia (very poor) in terms of the quality of GCG implementation (Dwiridotjahjono, 2009).

\section{H3: The Influence of Company Status on the Company's Financial Performance}

These results indicate that the company's status has an effect on the company's financial performance because the significance value is 0.021 . This means that if there is a change in the company's status from a private company (Non Plc.) to a public listed company (Plc.), it will have a positive impact on the company's financial performance.

In addition, the status of a public company will increase access to capital and become exposed. With easy access to capital will be able to support the company's investment plan well.

\section{v. CONCLUSION}

Based on the results of research and analysis of 13 companies based on the 2019 annual report, it can be concluded:
1. Company status affects GCG because the significance level is 0.000 , so hypothesis 1 is accepted.

2. CG affects the company's financial performance because the significance level is 0.019 , so hypothesis 2 is accepted.

3. Company status affects the company's financial performance because the significance level is 0.021 , so hypothesis 3 is accepted.

\section{REFERENCES}

[1]. Affi Arizka, H. (2019). Analisis Pengaruh Corporate Perception Governance Index pada Kinerja Operasional dan Nilai Pasar Perusahaan. Fakultas Ekonomi Universitas Islam Indonesia Yogyakarta.

[2]. Biuty, A. M., \& Triwacananingrum, W. (2018). Analisa Good Corporate Governance , Pengaruhnya Pada Financial Performance Di Perusahaan Yang Terdaftar Pada Corporate Governance Perception Index (Cgpi). Monex: Journal Research Accounting Politeknik Tegal, $7(2)$, 450-457. https://doi.org/10.30591/monex.v7i2.946

[3]. Darwis, H. (2009). Pengaruh Mekanisme Corporate Governance Terhadap Kinerja Perusahaan. Jurnal Akuntansi Dan Manajemen, STIE YKPN Yogyakarta, 19(3), 155-172.

[4]. Demise, N. (2006). OECD principles of corporate governance. Corporate Governance in Japan: From the Viewpoints of Management, Accounting, and the Market, 109-117. https://doi.org/10.1007/978-4-431-30920-8_10

[5]. Devina, S., \& Yuliana, G. (2019). Effect of Good Corporate Governance on Profitability. Journal of Auditing, Finance, and Forensic Accounting (JAFFA), 74(2), 44-96. https://doi.org/https://doi.org/10.21107/jaffa.v7i 2.6427

[6]. Dwiridotjahjono, J. (2009). Penerapan Good Corporate Governance: Manfaat Dan 
Tantangan Serta Kesempatan Bagi Perusahaan Publik Di Indonesia. Jurnal Administrasi Bisnis Unpar, $5(2)$, $101-112$. https://doi.org/10.26593/jab.v5i2.2108.

[7]. Ghozali, I. (2013). Aplikasi Analisis Multivariate Dengan Program IBM SPSS 21 Update PLS Regresi.

[8]. Hakim, M. F. Al, \& Nuzula, N. F. (2018). Pengaruh Corporate Governance dan Struktur Modal Terhadap Profitabilitas (Studi pada Perusahaan Perbankan yang Terdaftar di Bursa Efek Indonesia Periode 2012-2016). Jurnal Administrasi Bisnis (JAB), 61(1), 191-200.

[9]. Hidayat, F. S., Rizal, M., \& Arifianti, R. (2019). Analisis Pengaruh Dari Corporate Governance Perception Index (CGPI) Dan Kebijakan Dividen Terhadap Nilai Perusahaan BUMN. Jurnal Manajemen Pelayanan Publik, 2(1), 64. https://doi.org/10.24198/jmpp.v2i1.21576

[10]. Iba, Z., \& Bariah, C. (2013). Mengenal Prinsip Dan Penerapan Corporate Governance Dalam Mendukung Pengungkapan Informasi. Jurnal Kebangsaan, 2(3), 17-25.

[11]. Indarti, M. K., \& Extaliyus, L. (2013). Pengaruh Corporate Governance Preception Index (CGPI), Struktur Kepemilikan, dan Ukuran Perusahaan Terhadap Kinerja Keuangan. Jurnal Bisnis Dan Ekonomi, 20(2), 171-183. https://doi.org/10.1017/CBO9781107415324.004

[12]. Kelvianto, I., \& Mustamu, R. H. (2018). Implementasi Prinsip-Prinsip Good Corporate Governance Untuk Keberlanjutan Usaha Pada Perusahaan Yang Bergerak Di Bidang Manufaktur Pengolahan Kayu. Agora, 6(2), 1-7.

[13]. McKinsey \& Company. (2000). Investor opinion survey on Corporate Governance. (June), 1-18.

[14]. Mitton, T. (2000). A Cross-Firm Analysis of the Impact of Corporate Governance on the East Asian Financial Crisis. Journal of Financial Economics, 64, 215-241. https://doi.org/10.1016/S0304-405X(02)00076-4
[15]. Purwantara, A., \& Prasetyo, A. B. (2018). Analisis Pengaruh Corporate Governance Terhadap Financial Distress Dan Financial Performance. Jurnal Riset Akuntansi Departemen Akuntansi Fakultas Ekonomika Dan Bisnis Universitas Diponegoro, 6(1), 1-11.

[16]. Siregar, N. F., \& Nuzula, N. F. (2018). Pengaruh Corporate Governance Dan Profitabilitas Terhadap Nilai Perusahaan (Studi Pada Perusahaan Pertambangan Yang Terdaftar Di Bursa Efek Indonesia Periode 2016-2018). Jurnal Administrasi Bisnis (JAB), 79(1), 1-10.

[17]. Theacini, D. A., \& Wisadha, I. G. S. (2014). Pengaruh Good Corporate Governance, Kualitas Laba dan Ukuran Perusahaan Pada Kinerja Perusahaan. Jurnal Akuntansi Universitas Udayana, 3, 733-746.

[18]. Umar, F. (2001). Implementasi Good Corporate Governance di Indonesia. Jurnal Ekonomi Dan Kewirausahaan, 10(2), 129-138.

[19]. Usman, A. G., Saleh, L. M. I., Negeri, M., Mangkurat, L., Kalimantan, P., \& Usman, A. G. (2014). Pengaruh Good Corporate Governance terhadap Kinerja Keuangan Perbankan Syariah di Indonesia. 1-10.

[20]. UU Nomor 40 tahun 2007 tentang Perseroan Terbatas. (2007). 67(6), 14-21.

[21]. Widodo, F. A. (2012). Peran Corporate Governance Perception Index Serta Ukuran Perusahaan Terhadap Kinerja Keuangan Perusahaan Pada Hasil Survei The Indonesian Institute For Corporate Governance (IICG) Periode 2010-2012.

[22]. Windah, G. C., \& Andono, F. A. (2013). Pengaruh Penerapan Corporate Governance Terhadap Kinerja Keuangan Perusahaan Hasil Survei the Indonesian Institute Perception Governance (Iicg) Periode 2008-2011. Jurnal Ilmiah Mahasiswa Universitas Surabaya, 2(1), 1-20.

[23]. Zhuang, J., Edwards, D., Webb, D., \& Capulong, M. (2000). Corporate governance and 
finance in East Asia: a study of Indonesia, Republic of Korea, Malaysia, Philippines, and Thailand.

\section{Cite this article as :}

Rahmadoni, "The Effects of Good Corporate Governance and Company Status on The Company Financial Performance", International Journal of Scientific Research in Science and Technology (IJSRST), Online ISSN : 2395-602X, Print ISSN : 23956011, Volume 8 Issue 4, pp. 348-359, July-August 2021. Available at doi : https://doi.org/10.32628/IJSRST218462

Journal URL : https://ijsrst.com/IJSRST218462 